\title{
Pesticide Utilisation, Regulation and Future Prospects in Small Scale Horticultural Crop Production Systems in a Developing Country
}

\author{
J. Karungi ${ }^{1}$, S. Kyamanywa ${ }^{1}$, E. Adipala ${ }^{1}$ and M. Erbaugh ${ }^{2}$ \\ ${ }^{1}$ Crop Science Department, Makerere University, Kampala \\ ${ }^{2}$ The Ohio State University, Columbus, Ohio \\ ${ }^{1}$ Uganda, \\ 2USA
}

\section{Introduction}

Uganda has a largely agrarian based economy with $85 \%$ of its nearly 35 million people living in rural areas and $80 \%$ of its labor force engaged in agricultural production as their primary form of livelihood. The agriculture sector also accounts for 40 percent of GDP and $85 \%$ of export earnings with $90 \%$ of this being generated by crop production. Horticultural production is one of the fastest growing agricultural sub-sectors with a growth rate of $20 \%$ per year. It contributes to value addition, income diversification and foreign exchange earnings through exports (UIA, 1999). Horticultural production in Uganda is dominated by small scale producers (2ha. or less) who produce for both local and export markets. The most important horticultural crops in the vegetable category include tomato, green beans, cowpea, pepper, onion, crucifers, and Amaranthas spp. Because of ravages of pests and diseases on these moderate to high value crops, pesticides are among the key inputs on these crops.

The increased use of chemical pesticides on horticultural crops has raised a number of economic, ecological and health concerns. Economic concerns arise from the over reliance and use of chemical pesticides which increase the costs of production. Indiscriminate use of pesticides has resulted in ecological problems of common pests developing resistance, elimination of natural enemies and other beneficial arthropods, and environmental pollution. Human health concerns focus on risks from shortcomings in protective clothing, large deviations from recommended doses/situations, and excessive run-off into the soil and water sources. These concerns are exacerbated by poorly regulated internal markets for pesticides that have fostered usage of banned or outdated products; creating a situation that if not stopped will negatively impact on horticultural exports to countries with more stringent regulatory requirements for fresh crop produce. Meeting these food safety requirements has become a major challenge for the fresh produce export sector of many African countries. To ensure and maintain export compliance, grower and consumer safety, and environmental integrity; farmers, government and development partners are developing programmes designed to improve pesticides usage, regulation and management on horticultural crops. In this chapter, three important horticultural crops grown in Uganda- 
cowpea, hot pepper and tomato - have been selected to illustrate trends in pesticide usage and regulation, and the development and application of alternative pest management practices through farmer participation and training.

Cowpea (Vigna unguiculata) is an important legume in the north and north eastern parts of the country that receive little rainfall $(800-1000 \mathrm{~mm}$ per annum). Cowpea growers range from those who market all they produce (commercial) to those who consume all that the grow (subsistence). Many assert that it is not feasible to grow the crop commercially without the use of insecticide sprays (Jackai et al., 1985; Karungi et al., 2000). Hot pepper (Capsicum chinense) is an important fresh export crop. Uganda has been the market leader for supply of high quality hot peppers to EU market due to conducive production conditions in the country (UIA, 2009). It is mainly grown in the districts of central and western Uganda. Pests and diseases constitute a major limiting factor in hot pepper production. Insect pests alone account for about $20-40 \%$ yield losses (Asawalam et al, 2007). Farmers often apply chemical pesticides on a calendar basis to avoid risk of yield loss. However, as a fresh product export, mainly to the European Union, hot peppers need to meet international safety standards with regard to pesticide residue levels. Failure to comply with international food safety standards is a growing problem for many developing countries and an obstacle to accessing these lucrative international markets. Thus, if Ugandan hot peppers are to be marketed internationally, there is a need to ensure that their production complies with these pesticide usage standards. Tomato (Solanum lycopersicum) is the most important locally marketed vegetable in Uganda (Kasenge et al; 2002; Ssonko et al., 2005). Tomato production is a source of employment and income, and contributes to food security for large numbers of rural and peri-urban populations (Mwaule, 1995; Mukiibi, 2001). Yield losses due to pests and diseases are among the most important constraints resulting in excessive use of chemical pesticides by farmers.

\section{Status of pesticide utilization - Case studies}

In the last two decades, the Department of Crop Science of Makerere University and development partners have worked closely with horticultural crops farming communities in different parts of the country to develop integrated pest management systems conducive to local conditions. As rule of thumb, baseline studies collecting quantitative and qualitative data on priority pests and farmers' perceptions of pest control measures, including utilization of pesticides, from the farming communities have formed the first step in the mode of operation. Results from these studies have then provided the foundation for development and dissemination of specific interventions for the farming communities.

Cowpea: to answer questions regarding pesticide use and perceived efficacy on pests, a multiple cases study of 18 farmers categorised under subsistence, dual purpose and commercial was conducted in the growing districts of Pallisa, Kumi and Katakwi in eastern and north eastern Uganda over two consecutive years (Isubikalu et al., 2000). Findings showed that pesticides were used in the districts of Pallisa and Kumi as the main pest control strategy because the varieties grown there were susceptible to pests. Katakwi had only the subsistence category which did not use pesticides. In Pallisa and Kumi, farmers were routinely using a variety of insecticides at varying rates and frequencies of application in cowpea production (Tables 1, 2). Most of the pesticides used on cowpea belonged to the organophosphate or synthetic pyrethroid chemical groups. Usage was found to be specific to the type of farmer (Table 2). Commercial cowpea growers sometimes applied as many as 
8-10 sprays a growing season (70-80 days), and on occasion used tank-mixtures of different pesticides on cowpea (Tables 1,2). Subsistence farmers had the lowest frequency of pesticide application (1-3 times), which was attributed to delayed application of first spraying and long spray intervals (14-20 days). Although poverty was a reason for the low frequency of pesticides application among subsistence farmers; high demand and need for pesticide-free young tender leaves, a local popular vegetable dish appeared to be the most important reason. Choice of pesticides depended on the farmer's perception of its efficacy on pests, type and intensity of pests, crop growth stage, and availability of the pesticide (Isubikalu et al., 2000).

\begin{tabular}{|c|c|c|c|c|c|}
\hline Pesticide & Rates used & $\mathrm{C}$ & $\mathbf{D}$ & $S$ & Total \\
\hline \multirow{4}{*}{$\begin{array}{l}\text { Ripcord } \\
\text { (Cypermethrin) }\end{array}$} & $50 \mathrm{ml}$ in $15 \mathrm{l}$ of water & 1 & - & - & 1 \\
\hline & $100 \mathrm{ml}$ in 201 of water & - & - & 1 & 1 \\
\hline & $10 \mathrm{ml}$ in 51 of water & & 1 & - & 1 \\
\hline & $50 \mathrm{ml}$ in 201 of water & - & 1 & - & 1 \\
\hline \multirow{6}{*}{$\begin{array}{l}\text { Super ambush } \\
\text { (Lamda cyhalothrin) }\end{array}$} & $40 \mathrm{ml}$ in 201 of water & 1 & 1 & 2 & 4 \\
\hline & $40 \mathrm{ml}$ in 161 of water & 1 & - & - & 1 \\
\hline & $30 \mathrm{ml}$ in 161 of water & 1 & - & - & 1 \\
\hline & $50 \mathrm{ml}$ in 201 of water & 1 & - & - & 1 \\
\hline & $30 \mathrm{ml}$ in 201 of water & 1 & - & - & 1 \\
\hline & $25 \mathrm{ml}$ in $15 \mathrm{l}$ of water & & & 1 & 1 \\
\hline \multirow{2}{*}{ Agrothoate (Dimethoate) } & $30 \mathrm{ml}$ in 201 of water & 2 & 2 & 2 & 6 \\
\hline & $30 \mathrm{ml}$ in $15 \mathrm{l}$ of water & 1 & - & - & 1 \\
\hline \multirow{2}{*}{ Dimecron (Phosphamidon) } & $30 \mathrm{ml}$ in 201 of water & - & 1 & - & 1 \\
\hline & $40 \mathrm{ml}$ in 201 of water & - & - & 1 & 1 \\
\hline Dursban (Chlorpyrifos) & $40 \mathrm{ml}$ in 201 of water & 1 & - & - & 1 \\
\hline \multirow{5}{*}{$\begin{array}{l}\text { Sumithion } \\
\text { (Fenitrothion) }\end{array}$} & $50 \mathrm{ml}$ in 201 of water & - & 1 & 1 & 2 \\
\hline & $40 \mathrm{ml}$ in 201 of water & - & 1 & - & 1 \\
\hline & $30 \mathrm{ml}$ in $15 \mathrm{l}$ of water & - & - & 1 & 1 \\
\hline & $30 \mathrm{ml}$ in 171 of water & 1 & - & - & 1 \\
\hline & $20 \mathrm{ml}$ in 201 of water & - & - & 1 & 1 \\
\hline \multirow[t]{2}{*}{ Agrocytrin (Cyopermethrin) } & $50 \mathrm{ml}$ in 201 of water & - & 1 & 1 & 2 \\
\hline & $40 \mathrm{ml}$ in 201 of water & - & 1 & - & 1 \\
\hline Super ambush+Dimecron & $\begin{array}{c}20 \mathrm{ml} \text { ambush }+10 \mathrm{ml} \text { Dimecron in } 201 \text { of } \\
\text { water }\end{array}$ & - & 1 & - & 1 \\
\hline Sumithion+Agrocythrin & $\begin{array}{c}15 \mathrm{ml} \text { Sumithion }+20 \mathrm{ml} \text { Agrocythrin in } 201 \\
\text { of water }\end{array}$ & 1 & - & - & 1 \\
\hline $\begin{array}{l}\text { Sumithion +Thionex } \\
\text { (Endosulfan) }\end{array}$ & $\begin{array}{c}20 \mathrm{ml} \text { Sumithion }+20 \mathrm{ml} \text { Thionex in } 201 \text { of } \\
\text { water }\end{array}$ & 1 & - & - & 1 \\
\hline
\end{tabular}

Table 1. Types and rates of pesticides used by different types of cowpea growers Words in parentheses are names of the active ingredients; $\mathrm{C}=$ commercial farmer; $\mathrm{D}=$ dual purpose farmer; $S$ = subsistence farmer; 1 = litres. Adopted from: Adipala et al., 2000.

Erbaugh et al (2003) followed the case studies with a gender assessment study on pesticide decision making and usage among farmers in Pallisa, Kumi and Iganga districts. They found that sources of information on pesticide usage varied by gender with men appearing 
to have greater access than women to alternative and exogenous sources of information (Table 3). Decision making with regard to pesticide usage also varied with gender; men perceived pesticide decision making as largely a male affair, whereas women perceived pesticide decision making as a female or a household decision (Table 3). On the other hand, there was no relationship between gender and pesticides usage, as a matter of fact, pesticide usage was more related to the district than to gender, with both male and females in Kumi more likely to use pesticides than those in Iganga.

\begin{tabular}{ccccc}
\hline $\begin{array}{c}\text { Stage of the crop } \\
\text { (weeks after emergence) }\end{array}$ & \multicolumn{4}{c}{ Number of farmers (pesticide users only) } \\
\cline { 2 - 5 } $1-3$ & 5 & 3 & 1 & Total \\
\hline $3.5-5$ & 1 & 3 & 1 & 5 \\
$5.5-8$ & - & - & 2 & 2 \\
Total & 6 & 6 & 4 & 16 \\
Frequency & & & - & 3 \\
$8-10$ & 3 & 6 & 1 & 9 \\
$4-6$ & 2 & - & 3 & 4 \\
T-3 & 1 & 6 & 4 & 16 \\
\hline
\end{tabular}

Source: Isubikalu et al. 2000

Table 2. Frequency of insecticides usage and stage of crop sprayed in cowpea production

\begin{tabular}{|c|c|c|c|c|c|}
\hline \multicolumn{6}{|c|}{ Pesticide usage } \\
\hline All $(\mathrm{N}=200)$ & Male $(\mathrm{N}=96)$ & Female $(\mathrm{N}=104)$ & Total & $\mathrm{X}^{2}$ & phi \\
\hline Not using & 37 & 37 & 74 & \multirow{2}{*}{.188} & \multirow{2}{*}{.031} \\
\hline Using & 59 & 67 & 126 & & \\
\hline By district & Iganga $(\mathrm{N}=100)$ & Kumi (N=100) & & & \\
\hline Not using & 56 & 18 & 74 & \multirow{2}{*}{$30.97^{* *}$} & \multirow{2}{*}{$.394^{* *}$} \\
\hline Using & 44 & 82 & 126 & & \\
\hline \multicolumn{6}{|c|}{ Person in the household who makes pesticide use decision (pesticide users only) } \\
\hline All $(\mathrm{N}=200)$ & Male $(\mathrm{N}=59)$ & Female $(\mathrm{N}=67)$ & Total & $X^{2}$ & Cramer's V \\
\hline Men & 44 & 11 & 55 & & \\
\hline Women & 03 & 32 & 35 & $47.51^{* *}$ & $.614^{* *}$ \\
\hline Both & 12 & 24 & 36 & & \\
\hline
\end{tabular}

Pesticide usage: degrees of Freedom $=1 ;{ }^{*} \mathrm{p}<0.05 ;{ }^{* *} \mathrm{p}<0.01$

Pesticide use decision: $X^{2}$ and Cramer's V, Degrees of Freedom $=2 ;{ }^{*} \mathrm{p}<0.05 ;{ }^{* *} \mathrm{p}<0.01$. Source: Erbaugh et al., 2003.

Table 3. Role of gender in pesticide decisions and usage in Iganga and Kumi districts

Hot pepper: a rapid rural appraisal (RRA) to learn when, why, and what pesticides farmers were applying was conducted in 2007 in four districts (Luwero, Mpigi, Wakiso and Mukono) that form the main growing areas in Uganda. Results of the RRA showed that of 50 farmers who participated in the study, 47 used pesticides as the main control strategy for pests on hot pepper (Table 4). Fenvalerate, Dimethoate and Cypermethrin were the most commonly used insecticides. Sulphur was used by some farmers to manage mites and 
fungal diseases. In 2009, a more descriptive survey followed the RRA with one more district (Hoima) added to study area. A total of 84 farmers participated in the study, selected with the help of Sub County extension officers in the different districts.

\begin{tabular}{lccccc}
\hline District & Luwero & Mpigi & Wakiso & Mukono & Total \\
\hline No. farmers sampled & 10 & 15 & 10 & 15 & 50 \\
No. farmers using pesticides & 9 & 15 & 8 & 15 & 47 \\
Pesticides being used & & & & & \\
$\quad$ Cypermethrin & 3 & 2 & 5 & 8 & 18 \\
$\quad$ Fenvalerate & 5 & 13 & 2 & 7 & 27 \\
Dimethoate & 6 & 9 & 5 & 6 & 26 \\
$\quad$ Sulfur & - & 4 & 1 & - & 5 \\
Chlorpyrifos & - & - & 1 & - & 1 \\
$\quad$ Mancozeb & 2 & - & 1 & - & 3 \\
\hline
\end{tabular}

Source: IPM CRSP, 2007.

Table 4. Status of pesticide usage among hot pepper farmers in 2007

Results of the survey showed a slight change in trend in pesticide usage; all the interviewed farmers used insecticides to manage pests on hot pepper. Fenitrothion, Malathion and Flubendiamide were the additions to the list of pesticides being used on hot pepper. Farmers reported using more than one pesticide in a growing season, sometimes tank mixing pesticides to improve on the effect. Farmers acquired pesticide information from different sources with the bulk of the information originating from agricultural extension workers and produce buyers (Table 5).

\begin{tabular}{lcc}
\hline Source of information & Frequency & Percent (\%) \\
\hline Farmers' experiences & 5 & 6.0 \\
Pesticide providers & 3 & 3.6 \\
Extension workers & 52 & 61.9 \\
Produce buyers & 24 & 28.6 \\
Total & $\mathbf{8 4}$ & $\mathbf{1 0 0 . 0}$ \\
\hline
\end{tabular}

Source: Kwesiga et al (un published)

Table 5. Sources of information of pesticides among hot pepper growers

Farmers indicated that cost of pesticide was the main factor in deciding what product to use. From the information collected from the farmers, pesticides were estimated to cover between $18-21 \%$ of the total production cost of hot pepper.

Tomato: a baseline study in 1999 targeting peri-urban farmers in the districts of Wakiso and Mpigi to establish status of biotic constraints and prevailing management measures showed that control of the pests and diseases on tomato was mainly by synthetic pesticides. Farmers cited Ambush (Permethrin), Sumithion (Fenitrothion), Dimethoate, Nurelle-D (combination of Cypermethrin and Chlorpyrifos), Sherpa (Cypermethrin), Dursban (Chlorpyrifos), Salute (Trifluralin - herbicide), Zancor (Metribuzine - herbicide), Mancozeb (Dithane M45), Metalaxyl, and Ridomil (Mancozeb + Metalaxyl) as the pesticides used on the crop (Akemo et al., 2000). Fungicides were the most commonly used pesticides because fungal blights, especially Phytophthora are ever-present and if left unchecked result in crop losses greater 
than 75\% (Akemo et al., 2000). Farmers' response to this threat was to effect routine/calendar sprays with the fungicides with the majority of them spraying as often as twice a week throughout the tomato growing season. The majority of the farmers could not read labels to get the correct rates of application; the common practice was to use arbitrary measures like table spoons and bottle tops.

\section{Regulation of pesticide usage on specified horticultural crops in Uganda}

In all the presented crops, it was apparent that though necessary for increased productivity, the frequency of usage and handling aspects of pesticides left a lot to be desired. As a way to promote judicious pesticide usage, efforts have often taken the approach of developing and transfer of innovative techniques of minimising pesticide usage and/or promotion of alternative management options. Farmer training in judicious pesticide usage has gone hand in hand with IPM technology transfer. Another regulating mechanism has been through consumer demands and the need to comply to set standards with regard to fresh produce exports.

\subsection{Innovative spray schedules and alternative pest management options to reduce usage and impact of pesticides}

Cowpea: to reduce and regulate pesticides usage on cowpea, efforts were put in determining the most yield reducing insect pests so that only those can be treated chemically with focused/targeted sprays. Findings by Karungi et al. (2000) indicated that pesticide usage could be reduced from the 8-10 sprays a season to only 3 well timed ones, with higher returns (Tables 6, 7). Targeting pests that attack the crop at the budding, flowering and podding stages (corresponding to a spray at 30, 45 and 55 days after planting) contributed most in increasing marginal returns (Tables 6,7). When the spray schedule of the 3 targeted sprays was coupled with the cultural practices of timely planting and optimum plant density in an integrated pest management (IPM) strategy; the combination surpassed individual measures in terms of grain yield and marginal returns (Table 7). Moreover, this spray schedule would ensure that the young tender leaves that are normally picked for food in the vegetative stage of the crop are pesticide-free. The IPM package was duly recommended for transfer to farming communities.

\begin{tabular}{lccc}
\hline Spraying schedule & $\begin{array}{c}\text { Grain yield } \\
\mathrm{kg} / \mathrm{ha}\end{array}$ & $\begin{array}{c}\text { Yield gain } \\
\mathrm{kg} / \mathrm{ha}\end{array}$ & $\begin{array}{c}\text { Marginal } \\
\text { returnsa }\end{array}$ \\
\hline No insecticide applied (control) & 268.0 & - & - \\
Weekly throughout the vegetative stage & 590.1 & 322.0 & 0.66 \\
$\begin{array}{l}\text { Once at the vegetative, flowering, podding } \\
\text { stages }\end{array}$ & 983.7 & 715.8 & 2.18 \\
Once at the budding, flowering, podding stages & 1293.3 & 1025.3 & 3.12 \\
Weekly throughout the growing season & 1561.5 & 1293.5 & 1.77 \\
SED & 228.3 & - & - \\
\hline
\end{tabular}

Source: Karungi et al., 2000; aMarginal returns > 1 are profitable.

Table 6. Grain yields and marginal returns for different insecticide spray schedules 


\begin{tabular}{lccccc}
\hline & No control ${ }^{1}$ & $\begin{array}{c}\text { Cultural } \\
\text { control }^{2}\end{array}$ & $\begin{array}{c}\text { Chemical } \\
\text { control }^{3}\end{array}$ & $\begin{array}{c}\text { Combined } \\
\text { control }^{4}\end{array}$ & SED \\
\hline Aphids score/plant & 1.8 & 1.4 & 1.0 & 1.1 & 0.07 \\
Thrips/20 flowers & 70.5 & 92.0 & 19.8 & 14.0 & 7.8 \\
Grain yield kg/ha & 152.0 & 279.3 & 935.1 & 1135.5 & 130.0 \\
Yield gain kg/ha & - & 127.3 & 783.1 & 983.5 & $\mathrm{NA}$ \\
Marginal returns & - & - & 2.12 & 2.66 & $\mathrm{NA}$ \\
\hline
\end{tabular}

NA - not applicable as they were derived from grain yield (kg/ha). Source: Karungi et al., 2000.

Table 7. Grain yield and marginal returns for three different pest management methods

Hot pepper: as a fresh export produce pesticides have to be used as judiciously as possible if the produce is to comply with internationally set standards of pesticide residues. Intervention efforts commenced with a study assessing the effect of a biological pesticide (Azadirachtin, commonly known as Neem), an inorganic pesticide (Sulphur), and prophylactic soil dressing treatments imposed on two different cropping systems of hot pepper (Karungi et al., 2010). Results from two growing seasons indicated that plants receiving the novel pesticide treatments yielded significantly better than the untreated control regardless of pesticide type (Table 8). In the first growing season of 2008, plants receiving applications of neem-only sprays had the highest fruit yield (Table 8). Further research on the crop is on-going to constitute a package that can be disseminated to farmers.

\begin{tabular}{clcc}
\hline Season & Treatment & No. branches/plant & $\begin{array}{c}\text { Fruit weight } \\
\text { gm/fruit }\end{array}$ \\
\hline $2007 \mathrm{~B}^{+}$ & Prophylactic carbofuran treatment & 3.50 & 11.16 \\
& Weekly sprays of neem & 3.83 & 11.85 \\
& Prophylactic carbofuran + neem & 3.83 & 11.91 \\
& Untreated control & 3.50 & 7.96 \\
& Mean & 3.67 & $\mathbf{1 0 . 7 2}$ \\
& SE & $\mathbf{0 . 2 2 0}$ & $\mathbf{0 . 7 4 6}$ \\
Pro8A $^{+}$ & Prophylactic carbofuran treatment & 4.80 & 9.27 \\
& Weekly sprays of neem & 5.07 & 10.22 \\
& Prophylactic carbofuran + neem & 5.03 & 9.47 \\
& Sulphur sprays (every 10 days) & 5.27 & 9.53 \\
& Untreated control & 4.07 & 8.27 \\
& Mean & $\mathbf{4 . 8 5}$ & $\mathbf{9 . 3 5}$ \\
SE & $\mathbf{0 . 5 7 9}$ & $\mathbf{0 . 4 0 2}$ \\
\hline
\end{tabular}

$+2007 \mathrm{~B}$ denotes the second rainy season (August-November 2007) of 2007; ${ }^{+}$2008A denotes the first rainy season (March-June) of 2008. Source: Karungi et al., 2010.

Table 8. Effect of pesticide treatment on branching level and fruit weight of hot pepper

${ }^{1}$ Cowpea at $60 \times 20 \mathrm{~cm}$ (recommended);

${ }^{2}$ Cowpea at $30 \times 20 \mathrm{~cm}$ planted at on-set of rains (close spacing + early planting);

${ }^{3}$ Cowpea at $60 \times 20 \mathrm{~cm}$ sprayed 8 times in a season (weekly, starting two weeks after emergence);

${ }^{4}$ Cowpea at $30 \times 20 \mathrm{~cm}$, planted at onset of rains and sprayed once at budding, flowering and podding stages (3 sprays); 
Tomato: a study examining effect of different pesticide spray schedules, cover cropping, and innovative technologies on incidence of fungal diseases and yield of tomato was the first research to be undertaken. A trial was laid out in a RCBD, with 4 replicates and 8 treatments i.e., treatment $1=2$ spray applications of the fungicide Dithane M45 (Mancozeb) per week; 2 = one spray application of Dithane M45 per week; 3 = Pre-established cover crop (Siratro) mulch with no pesticide; 4 = one spray application of Dithane M45 per week + cover crop mulch; $5=2$ spray applications of Dithane 45 per week + cover crop mulch; $6=$ Bakers' yeast applications once a week + cover crop mulch; $7=$ Bakers' yeast with no mulch; and $8=$ Control (no spray and no cover crop). Results indicated that use of Dithane M45 significantly increased yields; one spray of Dithane M45 per week was found to be more effective than two sprays per week in increasing tomato yield; combining cover cropping with one spray of Dithane M45 per week gave the highest yields (Figure 1; Akemo, 2000). For the period 2000 to date, more alternative pest management options have been developed to help reduce pesticide usage on tomato notably use of the bacterial wilt resistant tomato variety MT56, staking, mulching and reduced pesticide usage. These components have been incorporated into an IPM 'basket' that has been disseminated to tomato farmers.

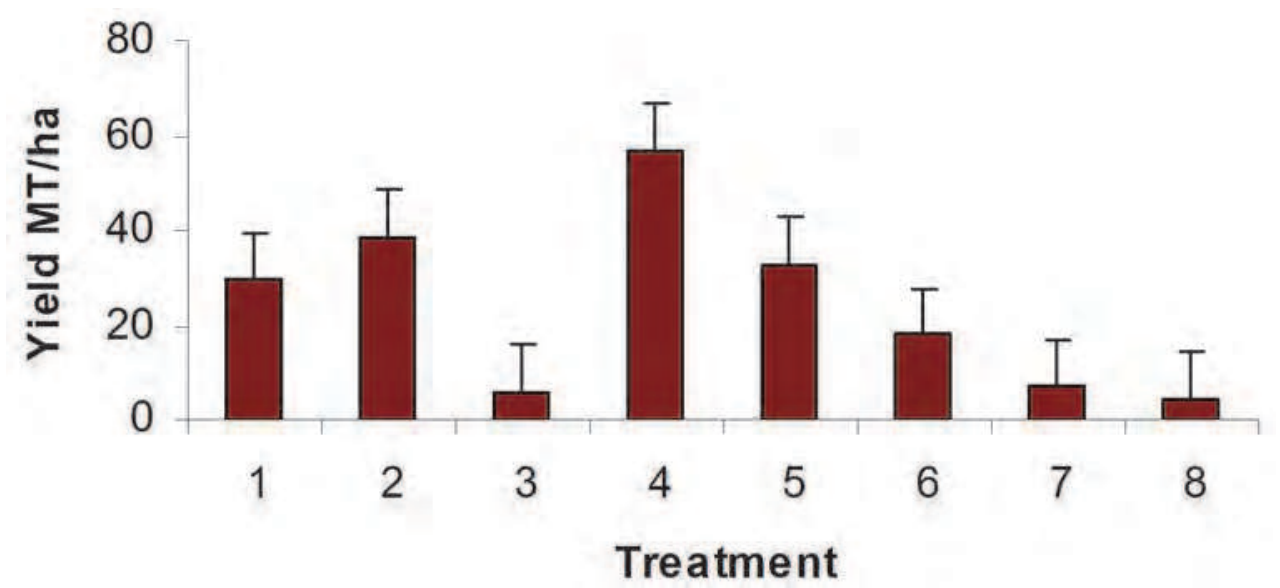

Fig. 1. Effect of different spray schedules of fungicide and/or alternative management options on tomato. Treatment $1=2$ sprays of Dithane M45 per week; 2 = one spray of Dithane M45 per week; 3 = Pre-established cover crop (Siratro) mulch with no pesticide; 4 = one spray of Dithane M45 per week + cover crop mulch; 5 = 2 sprays of Dithane M45 per week + cover crop mulch; 6 = Bakers' yeast applications once a week + cover crop mulch; 7 = Bakers' yeast with no mulch; and $8=$ Control (no spray and no cover crop). Source: Akemo et al., 2000.

\subsection{Farmer training for pesticide regulation}

IPM strategies though viable as presented above, are knowledge-based and effective implementation requires investments in farmer training and participation.

Cowpea: because of the great returns of the IPM package comprising of 3 targeted sprays in a growing season coupled with the cultural practices of timely planting and optimum plant density (Table 7), efforts were put in ensuring that cowpea growers get to experience it for 
themselves. The farmer field school (FFS) approach was chosen for the technology transfer process in three districts in north eastern Uganda. The FFS approach takes into account farmers' actual conditions and incorporates a 'learning by doing' approach, and had previously demonstrated that farmers can absorb IPM strategies, reduce their dependence on pesticides, and increase their ability to be decision-makers in their own fields (Chambers et al., 1989). The cowpea IPM FFS curriculum included sessions on safe pesticide usage and handling in addition to the IPM practices sessions. A total of 166 cowpea farmers were trained. When a post-test was done on the farmers that had participated in the FFS in Kumi and Pallisa districts, results showed that $76 \%$ and $50 \%$ of the farmers were using the recommended 3 targeted sprays schedule in Kumi and Pallisa, respectively (Figure 2). The success of the approach on cowpea led to the scaling up of the methodology to impart safe usage and handling procedures and IPM strategies to growers of cabbage (Slide 1), and groundnuts in other parts of the country.

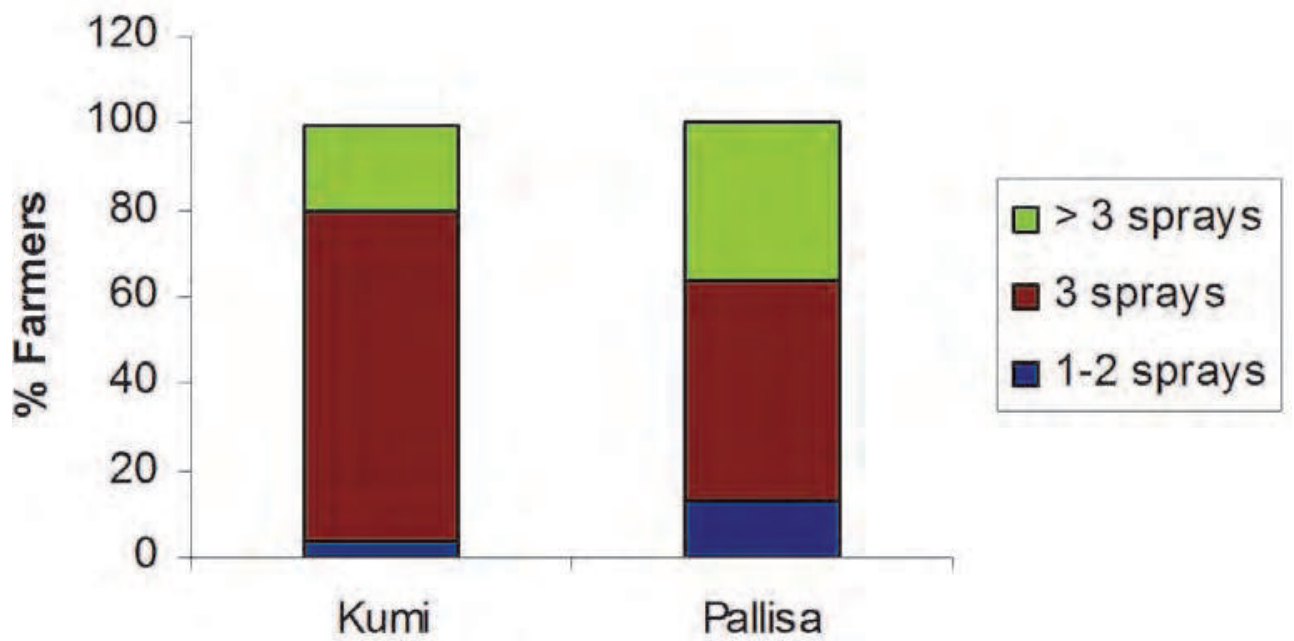

No. sprays per growing season

Fig. 2. Farmers' pesticide spray schedules after technology transfer through FFS (Source: Karungi-Tumutegyereize \& Adipala, 2004)

Tomato - an IPM package comprising of a bacterial resistant variety MT56, the cultural practices of mulching and staking, and reduced pesticide spray regimes was participatorily transferred to a pilot of 60 farmers in Busukuma Sub County, Wakiso district in Central Uganda over the period 2005-2008. Thereafter an impact assessment was executed and findings revealed that farmers only applied individual components of the IPM package; especially the bacterial wilt resistant variety MT 56. Surprisingly, only $6.7 \%$ of the respondents were practicing the recommended reduced pesticide usage schedule. 


\begin{tabular}{lc}
\hline Component of the IPM package being used & \% Farmers using the component \\
\hline Resistant tomato variety MT56 & 73.3 \\
Mulching & 13.3 \\
Reduced pesticide use (one spray a week) & 6.7 \\
Total & 93.3 \\
\hline
\end{tabular}

Source: IPM CRSP, 2009

Table 9. Assessment of adoption levels of transferred tomato IPM package

Results of the impact assessment also indicated that safety procedures were still not being followed as farmers did not wear protective clothing when mixing or applying pesticides; farmers did not read labels on the pesticides; and farmers did not observe the pre-harvesting waiting periods after applying pesticides (IPM CRSP, unpublished).

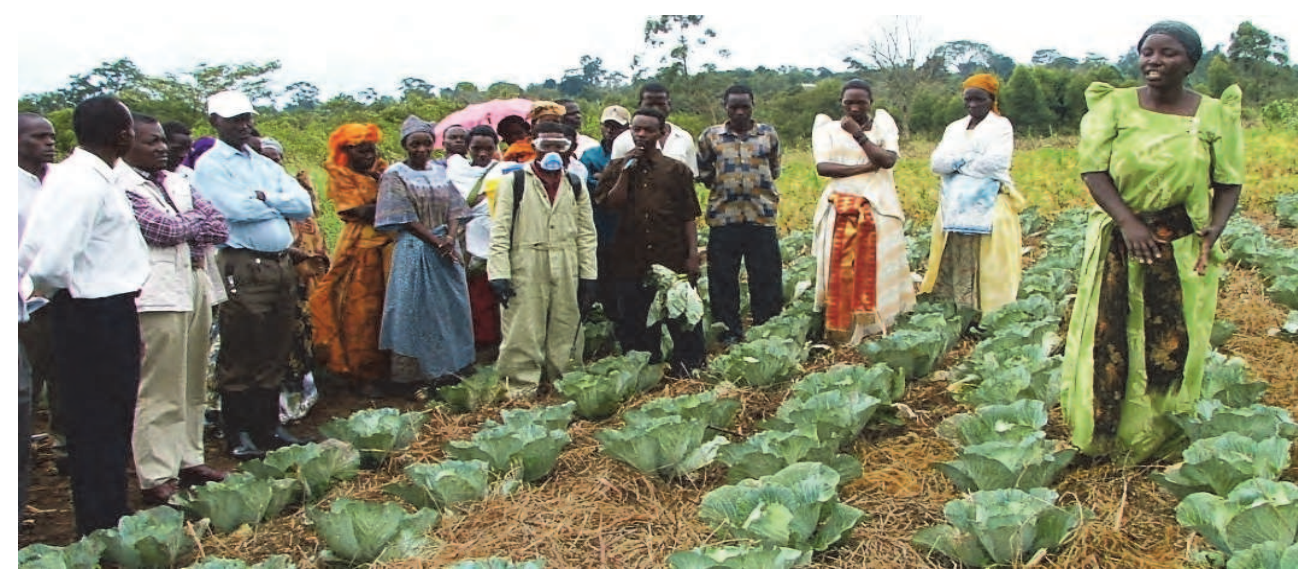

Slides 1. FFS beneficiaries demonstrating to fellow growers about safe pesticide usage

\subsection{International markets' effort to regulate pesticide usage}

In an endeavour to protect consumers of horticultural products from Africa and Uganda in particular, the European Union (EU), the main importer, constituted the Pesticides Initiative Programme (PIP) as a regulation strategy to ensure compliance of the private fresh produce sector through training in IPM and traceability. PIP helps rural producers in Africa, Caribbean and Latin American countries to stay competitive in the face of globalisation and supply chain integration and to cope with the present and future challenges imposed by food safety regulations and commercial requirements (Schiffers, 2007). In Uganda, PIP works with exporters (19 so far) and a selected number of out-growers (>1000) dealing mainly in pineapple, banana, green bean, okra, papaya, and hot pepper; in promoting IPM especially use of bio-pesticides and natural predators as an effective means of reducing pesticide residues in food, thus addressing the risks posed to human health and the environment as well as the costs brought about from the use of pesticides (PIP, 2006). PIP is engaged in capacity building through training for sustainable implementation and maintenance of food safety systems. By 2006, 30 trainers, and 67 participants selected from 
service sectors had been trained and are currently working as service providers. In-company training sessions to train the members of Export companies' staff in supervisory position such as team leaders, field assistants and lead farmers had also been effected. The training usually takes place on a company's own premises and includes topics such as hygiene, safe use of pesticides, safe production practices, and record keeping. PIP is also currently supporting the national pesticides regulatory body (Agricultural Chemicals Board) in Uganda in its endeavour to improve registration procedures in the country especially upgrading of the pesticide approval process, and the skills of the registrar and registration officers in the evaluation of dossiers submitted for registration of pesticides as well as advising the Ministry of Agriculture to ensure that Uganda's pesticide policy and regulatory framework is harmonised with EU regulations.

\section{General discussion}

High frequencies of pesticides application were reported on the presented horticultural crops in Uganda. Tomato was the heaviest consumer of pesticides at two routine sprays a week, a schedule that the majority of the farmers used even after involvement in IPM training programmes. This showed that farmers were reluctant to give up the 'insurance' against loss garnered from pesticide usage. Moreover, in Uganda, particular pesticides formulations are now within the purchasing power of more producers following the removal of the import tax on agricultural chemicals (Schaefers et al., 1999). Heavy usage of pesticides on tomato has also been reported from other countries in Africa; Ntow et al (2006) working on tomato in Ghana showed that farmers sprayed an average of 6-12 times a season, whereas it was 5-16 times or more per cropping season in Tanzania (Ngow et al., 2007). Such heavy use of pesticides results in frequent contact with pesticides, which can lead to significant health problems even though fungicides are the case in point. Fungicides are not easily observed to cause serious and acute damage to farmer's health but it has been reported that there is a long-term risk for cancer development and endocrine disruption resulting from farmer's exposure to fungicides containing mancozeb (Novikova et al., 2003). The dithiocarbamate family of fungicides are also suspected to have reproductive (Restrepo et al., 1990) and mutagenic effects in human cells (Puz-y-Mino et al., 2002).

Farmers were using arbitrary tank-mixtures of chemical pesticides as a way to increase effectiveness or save on labour. A similar situation was reported from Tanzania where a study on pesticides usage in small-scale vegetable farms revealed that a third of the interviewed farmers applied pesticides in tank-mixtures (Ngowi et al., 2007). In all cases, there were no specific instructions either from the labels or extension workers regarding these tank mixtures. Mixing of pesticides by inexperienced farmers is not encouraged because the combinations used are indiscriminate. The practice defies some of the basic principles of insecticide management. For instance, Metacalf (1980) in his recommendation of strategies for pesticide management, states that the use of mixtures of insecticides must be avoided, since mixtures of insecticides generally result in the simultaneous development of resistance. Biney (2001) working in Ghana attributed the increase in incidences of insect pest infestation of tomato after pesticide applications to indiscriminate combinations of pesticides, particularly of insecticides. Moreover, label instructions do not cover tankmixtures of pesticides and give no information on the compatibility of inert ingredients such as emulsifiers and wetting agents. It is riskier to mix two different types of formulations for 
example wettable powders with emulsifiable concentrates. Smit et al. (2002) observed that there was an interaction between fungicides, insecticides and water mineral content that influenced the efficacy of individual pesticide against fungal pathogens and insect mortality and some tank mixtures induced phytotoxicity on tomato. There is limited information on the reaction and effects of the mixtures being used in the case studies. In addition, farmers did not consider that unspecified tank mixing of pesticides could be less effective and cause adverse effects to their health or the environment. Instead, the tank mixing was carried out to save time, labour cost and with anticipation of high efficacy in pests and diseases control. Sherwood et al. (2005) also reported that potato farmers in Ecuador were mixing pesticides mainly to reduce costs associated with spraying.

Findings from the case studies and elsewhere in Sub Saharan Africa (Matthews et al., 2003; Ntow et al., 2006; Ngowi et al., 2007) show that internationally banned/restricted pesticides such as Carbofuran and Endosulfan are still being used by minimally educated farmers on horticultural crops. These pesticides pose a serious threat to human health and the environment. The problem is particularly widespread in sub-Saharan Africa, where the advent of liberalisation of agrochemical input markets has weakened quality control (FAO/WHO, 2001). Prior to liberalisation, there were relatively few actors involved in pesticide provision, which made regulation and control fairly simple. In Uganda, importation and distribution of pesticides and other agricultural inputs used to be conducted by the Government and its Parastatals, which had proper procedures for safe handling and distribution of pesticides. Entry of more firms into the market runs the risk of erosion of quality control and packaging standards, the breaching of national regulations and the unimpeded movement of banned or restricted chemicals across borders (Mudimu et al., 1995). It also raises concerns about the ability of regulatory agencies to control their activities, since it requires more vigorous scrutiny and screening of imports and monitoring of distribution and usage (Mudimu et al., 1995; Williamson, 2003), with huge financial and human resource implications for these agencies. Pesticide provision in a market-driven economy needs an effective regulatory framework in order to create full and fair competition, to protect the environment, to guarantee the quality of the products and to avoid the spread of pests and diseases (Shepherd and Farolfi, 1999). These are critical challenges for hard-pressed African regulators.

Most of the pesticides on the Ugandan market in particular are pesticides that have been around for a long time within a limited range. On record in 1999, 190 pesticide formulations had been registered (includes insecticide, fungicides, and herbicides), a pittance if compared to developed countries like the United States of America; where over 50,000 had been registered by that period (Schaefers et al., 1999). This is a great disadvantage to pesticide users who have limited choice for safe pesticides. This discrepancy in accessibility to safer pesticides between countries at different levels of economic development poses a challenge in developing IPM systems in some developing countries. Safer pesticides are either inaccessible or outside the income bracket of small scale farmers. For such countries to remain competitive in international export markets, the policy environment, particularly regarding registration of newer and safer agrochemicals has to be more conducive.

\section{Conclusions, recommendations and future prospects}

Pesticide usage on horticultural crops in Uganda in particular and sub Saharan Africa in general, has seen a steady increase over the last decade, regulation and management of 
pesticide usage is following the same trend albeit at a slower pace with more effort needed to ensure safety for users/handlers, consumers and the environment.

High levels of pesticide use in vegetables are not unavoidable and, whether producing for export or domestic markets, greater efforts must be made to help farmers grow vegetables economically, ecologically and without exposing themselves, workers or consumers to hazardous levels of pesticides. Pesticide provision and use can be made much safer and more rational when a concerted effort is made amongst exporters, pesticide companies and farmers to reduce hazardous and unnecessary use and to ensure cropping system sustainability and market acceptability of the produce. Safer, more sustainable methods of pest and crop management exist and are being used successfully by millions of small-scale farmers worldwide, delivering substantial yield, income and welfare benefits in some of the most challenging agro ecological environments. African governments and development partners should invest in adapting and refining these methods and in training and knowledge exchange as a priority in new programmes for smallholder intensification, in conjunction with crop varieties which do not lead to reliance on pesticides. Pesticide and pest management issues and policies must be considered in a more holistic context of crop management, marketing and better cost-benefit assessment, with opportunity for public participation in decision-making. The IPM/FFS approach is valuable on a project-by-project basis, but with government backing and supportive policies could help to transform production, and bring real benefits to small-scale vegetable producers.

Options for adapting existing pesticide channels to supply safer and more sustainable pest management products, such as biopesticides, chemicals based on insect pest behaviour, and insect growth regulators, need to be explored. Regulators can help by establishing fast-track systems for rapid registration of such products and enjoy better tax policies compared with chemical pesticides. Regional harmonization of pesticide registration is also an opportunity for overcoming registration problems. For example, this would encourage the adoption of a system of "reciprocity" in which the pesticide registration systems of the Great Lake countries would be mutually acceptable. In this manner, the costs of efficacy testing and quality testing could be shared, there would be less duplication of effort, and more resources would remain for the proper role of the private sector - enlightened enforcement.

Market signals, reinforced with well-informed consumer demand, better understanding and communication along the supply chain, and investment in capacity-building, provide the best options for tackling many of the factors which drive pesticide misuse and dependency and which under-resourced regulatory authorities have been unable to address. Consumer perception of pesticides and their residues in fresh produce as undesirable, can lead to stronger retailer controls over what producers may use, together with greater traceability requirements and the establishment of approved crop production protocols and their consequent uptake by growers, particularly with regard to pesticide requirement, choice and adherence to harvest intervals. If compliance to these stipulation yields better prices and/or preferential purchase from European importers, exporters and farmers would be hard-pressed to embrace the system.

\section{Acknowledgements}

The case studies presented in this paper were implemented with funding from USAID through IPM CRSP: East Africa Regional Programme, Rockefeller Foundation, and the Carnegie Corporation of New York. 


\section{References}

Akemo, M.C., Kyamanywa, S., Luther, G., Ssekyewa, C., Erbaugh, J.M. \& Warren, H. 2000. Developing IPM systems for tomato in Central and Eastern Uganda. IPMCRSP sixth Annual Report. No. 6:117-121.

Asawalam, E.F., Emeasor, K.C. \& Okezie, J.C. 2007. Control of pests of some capsicum species (pepper) cultivars using soil amendments in Umudike - Nigeria. Electronic Journal of Environmental, Agricultural and Food Chemistry, 6 (4): 1975-1979.

Biney, P.M., 2001. Pesticide use pattern and insecticide residue levels in tomato (Lycopersicum esculentum) in some selected production systems in Ghana. MPhil Thesis, University of Ghana, Legon.

Chambers, R., Pacey, R. A. \& Thrupp L. A., 1989. Farmer first: farmer innovation and agricultural research. Intermediate Technology Publications, London, $219 \mathrm{pp}$.

Erbaugh, M.J., Donnermeyer, J., Amujal, M. and Kyamanywa, S. 2003. The Role of Women in Pest Management Decision Making in Eastern Uganda. Journal of International Agricultural and Extension Education, 10(3): 71-81.

FAO/WHO (2001) Amount of poor-quality pesticides sold in developing countries alarmingly high. FAO/WHO press release, 1 February 2001.

IPM CRSP, 2007. IPM CRSP Annual Report. Office of International Research and Development Integrated Pest Management Collaborative Research Support Program (IPM CRSP), Virginia Tech, Blacksburg, USA.

Isubikalu, P., Erbaugh, J. M., Semana, A. R., \& Adipala, E. (2000). The influence of farmer perception on pesticide usage for management of cowpea field pests in eastern Uganda. African Crop Science Journal, 8(3), 317-326.

Jackai, L.E.N., Singh, S.R., Raheja, A.K. \& Wiedijk, F., 1985. Recent trends in the control of cowpea pests in Africa. In: Singh, S.R., Rachie, K.O. (Eds.), Cowpea Research, Production and Utilization. Wiley, New York, pp. 233-246.

Karungi, J., Adipala, E., Kyamanywa, S., Ogenga-Latigo, M.W., Oyobo, N. \& Jackai, L.E.N. 2000. Pest management in cowpeas. Part 2. Integrating planting time, plant density and insecticide application for management of cowpea field insect pests in eastern Uganda, Crop Protection, 19: 237-245.

Karungi, J., Agamile, P., Kovach, J. \& S. Kyamanywa, S. 2010. Cover cropping and novel pesticide usage in the management of pests of hot pepper (Capsicum chinense). International Journal of Tropical Insect Science, Vol. 30, No. 2, pp. 84-92.

Karungi-Tumutegyereize, J. \& Adipala, E. 2004. Enhancing the role of Makerere University in technology generation and dissemination. Implementation Report; Department of Crop Science, Makerere University, pp 51.

Kasenge, V., Akemo, M.C., Taylor, D.B., Kyamanywa, S., Adipala, E. \& Mugonola, B., 2001. Economics of fresh market tomato production by peri-urban farmers in Wakiso district. IPM CRSP, annual report, no.9:197-202, 2001/2002.

Matthews, G., Wiles, T., \& Baleguel, P. 2003. A survey of pesticide application in Cameroon. Crop Protection 22: 707-714.

Metcalf RL, Changing role of insecticides in crop protection. Annu. Rev. Entomol. 25:119-256 (1980).

Mukiibi, M. K. 2001. Agriculture in Uganda Vol. I General Information, Uganda Fountain Publishers, 486 pp. 9970022431. 
Mwaule, Y. W. 1995. Draft Report of the Consultancy on Tomato Research results in Uganda from 1980 -1995, GTZ -IPM Horticulture Reports. 85 pp.

Mudimu, G.D., Chigume, S. \& Chikanda, M. 1995. Pesticide use and policies in Zimbabwe. Pesticide Policy Project Publication Series, No. 2. Hanover, Germany: Institut für Gartenbauökonomie, University of Hannover, Germany.

Ngowi, A.V.F., Mbise, T.J., Ijani, A.S.M., London, L. \& Ajayi. O.C. 2007. Smallholder vegetable farmers in Northern Tanzania: Pesticides use practices, perceptions, cost and health effects. Available online 28 March 2007.

Novikova, I.I., Litvinenko, A.I., Boikova, I.V., Yaroshenko, V.A. \& Kalko, G.V. 2003. Biological activity of new microbiological preparations designed for plant protection against diseases of vegetable crops and potato, Mikol. Fitopatol. 37 (1) (2003), pp. 92-98.

Ntow, W.J., Gijzen, H.J., Kelderman, P. and Drechsel, P. 2006. Farmer perceptions and pesticide use practices in vegetable production in Ghana. Pest Management Science, 62:356-365.

PIP, 2006. Pesticide Initiative Programme and the Ugandan fruit and vegetable sector. www.coleacp.org/pip

Puz-y-Mino, C. Bustamente, G. Sanchez, M.E. \& Leone, P.E. 2002. Cytogenetic monitoring in a population occupationally exposed to pesticides in Ecuador, Environ. Health Perspect. 110:1077-1080.

Restrepo, M., Monoz, N., Day, N.E., Parra, J.E. de Romero, L. \& Nguyen-Dinh, X. 1990. Prevalence of adverse reproductive outcomes in a population occupationally exposed to pesticides in Colombia, Scand. J. Work Environ. Health 16 (1990), pp. 232238.

Schaefers, G.A., Hedlund, R.C. \& Kyamanywa, S. 1999. Report on pesticide use by strategic objective 1 partners and on Uganda's pesticide regulatory status. Task Order No. 1648.

Schiffers, B. 2007. How can rural producers in Africa become more competitive in the face of globalisation and supply chain integration? Second European Forum on Sustainable development, Berlin, Germany June 18-21, 2007. Working Group 1.4 .

Shepherd, A.W. \& Farolfi, S. 1999. Export crop liberalization in Africa, FAO Agricultural Services Bulletin 135, Rome, 89pp.

Sherwood, S. Cole, D., Crissman, C. \& Paredes, M. 2005. From pesticides to people: improving ecosystem health in the northern Andes. In: J. Pretty, (Ed). The Pesticide Detox. towards a more sustainable agriculture, Earthscan, London, pp. 147-164.

Smit, Z.K., Indjic, D., Belic, S. \& Miloradov, M., 2002. Effect of water quality on physical properties and biological activity of tank mix insecticide-fungicide spray, In: Paroussi, G., Voyiatzis, D., Paroussis, E. (Eds.), Proceedings of the Second Balkan Symposium on Vegetables and Potatoes (579), International Society Horticultural Science, Leuven, Belgium, pp., 551-556.

Ssonko, R.N., Njue, E., Ssebuliba, J.M. \& de Jager, A. 2005. Pro-poor Horticulture in East Africa and South Asia: the horticultural sector in Uganda. A publication of the International Society for Horticultural Science. Available from www.ishs.org (c) 2005 
UIA, 2009. Uganda investment authority: Investing in Uganda - potentials in fresh and minimally processed fruits and vegetables for export. Available from www.ugandainvest.com/admin/docs/Fresh\%20Minimally \%20Processed $\% 20$ Fruit s\%20Vegetables.pdf

Williamson, S. 2003. Pesticide provision in liberalised Africa: out of control? Agricultural Research and Extension Network. Network Paper No. 126. ISBN 0850036399. 


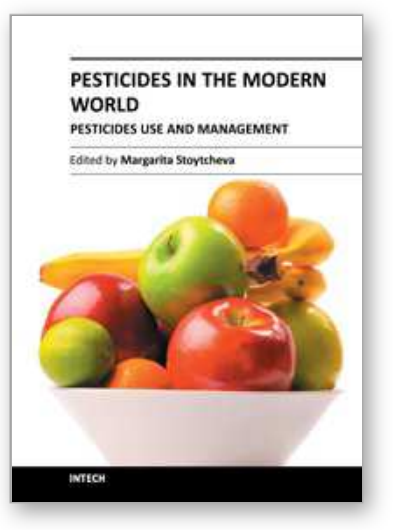

\author{
Pesticides in the Modern World - Pesticides Use and Management \\ Edited by Dr. Margarita Stoytcheva
}

ISBN 978-953-307-459-7

Hard cover, 520 pages

Publisher InTech

Published online 19, October, 2011

Published in print edition October, 2011

This book brings together issues on pesticides and biopesticides use with the related subjects of pesticides management and sustainable development. It contains 24 chapters organized in three sections. The first book section supplies an overview on the current use of pesticides, on the regulatory status, on the levels of contamination, on the pesticides management options, and on some techniques of pesticides application, reporting data collected from all over the world. Second section is devoted to the advances in the evolving field of biopesticides, providing actual information on the regulation of the plant protection products from natural origin in the European Union. It reports data associated with the application of neem pesticides, wood pyrolysis liquids and bacillus-based products. The third book section covers various aspects of pesticides management practices in concert with pesticides degradation and contaminated sites remediation technologies, supporting the environmental sustainability.

\title{
How to reference
}

In order to correctly reference this scholarly work, feel free to copy and paste the following:

J. Karungi, S. Kyamanywa, E. Adipala and M. Erbaugh (2011). Pesticide Utilisation, Regulation and Future Prospects in Small Scale Horticultural Crop Production Systems in a Developing Country, Pesticides in the Modern World - Pesticides Use and Management, Dr. Margarita Stoytcheva (Ed.), ISBN: 978-953-307-459-7, InTech, Available from: http://www.intechopen.com/books/pesticides-in-the-modern-world-pesticides-use-andmanagement/pesticide-utilisation-regulation-and-future-prospects-in-small-scale-horticultural-crop-productionS

\section{INTECH}

open science | open minds

\section{InTech Europe}

University Campus STeP Ri

Slavka Krautzeka 83/A

51000 Rijeka, Croatia

Phone: +385 (51) 770447

Fax: +385 (51) 686166

www.intechopen.com

\section{InTech China}

Unit 405, Office Block, Hotel Equatorial Shanghai

No.65, Yan An Road (West), Shanghai, 200040, China 中国上海市延安西路65号上海国际贵都大饭店办公楼405单元

Phone: +86-21-62489820

Fax: +86-21-62489821 
(C) 2011 The Author(s). Licensee IntechOpen. This is an open access article distributed under the terms of the Creative Commons Attribution 3.0 License, which permits unrestricted use, distribution, and reproduction in any medium, provided the original work is properly cited. 